\title{
DO INQUISITÓRIO AO ACUSATÓRIO(?): A NOVA REDAÇÃO DO ARTIGO 28 DO
} CPP.

\section{Gamil Föppel El Hireche ${ }^{1}$}

\section{Resumo}

O presente artigo analisa o artigo 28 do Código de Processo Penal, buscando responder em que medida a nova redação do dispositivo legal, dada pela lei 13.964/2019, insere um dado acusatório no processo penal brasileiro. Investiga-se, para tanto, os sistemas processuais penais, por meio de revisão bibliográfica, de maneira a concluir que a nova sistemática de arquivamento do inquérito representa, sim, em certa medida, o sistema acusatório, o qual ainda assim não resta definitivamente consagrado, haja vista que a leitmotiv do sistema inquisitorial (gestão da prova nas mãos do juiz) ainda é a uma realidade presente no processo penal brasileiro.

Palavras-Chave: Inquérito Policial, Arquivamento, Sistema Acusatório, Sistema Inquisitório, Gestão da Prova.

\section{INQUISITORIAL TO THE ACCUSATORY: A NEW WORDING OF ARTICLE 28 OF THE CPP.}

\begin{abstract}
The present paper aims to analyze Article 28 of the Code of Criminal Procedure, in order to answer to what extent the new wording of the legal text, established by Law 13.964/2019, inserts an accusatory character in the Brazilian criminal proceedings. Therefore, criminal procedural systems are investigated through a bibliographic diagnosis, so conclude that the new procedure for filing the inquiry represents, in fact, the accusatory system, which is still not completely established, considering that the leitmotiv of the inquisitorial system (of the judge as evidence manager) is still a reality present in the Brazilian criminal proceeding.
\end{abstract}

Keywords: Police investigation; Archiving of the investigation, Accusatory System; Inquisitorial System; Evidence Management

\section{Introdução}

Pós Doutorando em Direito Penal pela USP. Doutor em Direito Penal Econômico pela Universidade Federal de Pernambuco (UFPE). Mestre em Direito Penal pela Universidade Federal da Bahia (UFBA). Especialista em Ciências Criminais pelo Instituto de Estudos Luiz Flávio Gomes (LFG/SP). Pós-Graduado em Direito Penal Econômico e Europeu pela Universidade de Coimbra. Membro da Comissão de Juristas, nomeado pelo Senado Federal, para a Revisão do Código Penal. Membro da Comissão de Juristas, nomeado pelo Senado Federal, para a Revisão da Lei de Execuções Penais. Professor associado de Direito Penal e de Direito Processual Penal da Faculdade de Direito da UFBA, lecionando na graduação e no mestrado. Professor licenciado da UNB. Coordenador da Pós-Graduação em Ciências Criminais da Faculdade Baiana de Direito. 
O presente artigo busca fazer uma breve análise do modelo de arquivamento do inquérito policial recém implementado pela lei 13.964/2019. Com efeito, a novel legislação, cuja eficácia se encontra, em parte, suspensa sine die por ocasião da concessão da cautelar no bojo da Ação Direta de Inconstitucionalidade (ADI) 6.298, alterou substancialmente o procedimento de arquivamento do inquérito policial, previsto no art. 28 do Código de Processo Penal (CPP).

Nessa linha, o antigo modelo, ainda vigente, é representativo de um sistema penal fundado sobretudo em elementos inquisitoriais, capazes de transmutar a real função do juiz na persecução penal, entregando-lhe funções anômalas e contrárias aos fundamentos do sistema acusatório.

Ainda assim, mesmo que o art. 28 do CPP, no opinativo deste artigo, trate-se de disposição não recepcionada pela Constituição Federal de 1988, é ele o artigo em vigência, não tendo sido, até o presente momento, afastado pelo Supremo Tribunal Federal em qualquer eventual controle concentrado de constitucionalidade.

Dessa maneira, ainda, portanto, que representativo de um modelo sistêmico inquisitorial, o artigo 28 mantém a sua vigência, consubstanciando a regra do jogo e fazendo do arquivamento do inquérito policial um ato complexo, que demanda, de início, após o relatório policial, um pedido do órgão ministerial para, só em seguida, diante deste pedido ou promoção, demandar uma atuação jurisdicional no sentido de acatá-lo ou rejeitá-lo.

Essa relação triangular (Polícia, Ministério Público e Juiz) não tem qualquer razão de ser em um sistema penal cujo parâmetro constitucional seja uma carta que consagre o modelo acusatório de persecução penal ${ }^{2}$.

Muito certamente pela arguta crítica científica, a nova lei 13.964/2019 passou a integrar o ordenamento jurídico. Dentre as várias modificações por ela empreendidas, a que hoje se revela pertinente na análise deste artigo é aquela referente à modificação do modelo de arquivamento do inquérito policial.

A partir desse atual marco legislativo, a relação outrora triangular passa a ser composta por dois personagens: Polícia e Ministério Público. A antiga promoção de arquivamento agora perde sua natureza de mero pedido e converte-se em efetiva decisão por não denunciar, cabível exclusivamente ao membro do parquet.

2 No mesmo sentido, (PRADO, 2005, p. 365-366). 
Esse novo cenário, que verdadeiramente exclui o juiz da posição de revisor (ou vero acusador) dos atos administrativos do Ministério Público, representa, mesmo que timidamente, um certo avanço em direção à consagração efetiva do sistema acusatório.

É verdade que a lei modifica e institui aspectos muito mais evidentemente acusatórios, a exemplo do "Juízo de Garantias", de maneira que a escolha por investigar tão apenas o arquivamento do inquérito policial se dá por duas razões.

Primeiro, porque o tema, mesmo que somente uma fatia pequena das modificações empreendidas pela nova lei, parece sim suficientemente representativo da intenção legislativa no sentido de ampliar mecanismos acusatórios no sistema penal vigente.

Segundo, porque o tema em questão ainda não foi exaurido pela doutrina, sendo exceções alguns artigos publicados e disponíveis na rede mundial de computadores, a exemplo daqueles de autoria de Afrânio Silva Jardim ${ }^{3}$, Francisco Bastos Dirceu e Vladimir Aras ${ }^{4}$.

A ausência de diversos trabalhos a esmiuçarem a tratativa do novo arquivamento do inquérito, por mais que densas e brilhantes as exposições feitas pelos autores mencionados, revela a necessidade deste artigo, que não se pretende, evidente, um parâmetro definitivo para a análise da matéria.

\subsection{Objetivos}

Os objetivos deste artigo são basicamente dois. Primeiro, busca-se entregar ao leitor uma visão panorâmica sobre os dois principais sistemas teóricos de processo penal mencionados pela doutrina. Falar-se-á, brevemente, acerca do sistema inquisitório, para, em seguida, apresentar o surgimento histórico e as principais características do sistema acusatório, etapa imprescindível para que se compreenda com precisão a essência do novo arquivamento do inquérito policial.

Nessa linha, o presente artigo busca mostrar que o que define um sistema penal como acusatório ou inquisitório não é necessariamente a simples soma de suas características. A ideia central que transmite as noções de acusatório e inquisitório deve ser aquela já exposta por Jacinto Nelson de Miranda Coutinho, em diversas e múltiplas passagens, ao demonstrar que o mais importante, nessa análise, é a identificação do princípio reitor do sistema, tendo por critério a precisa identificação sobre a gestão da prova.

3 Cf. (JARDIM, 2020).

4 Veja-se (BARROS; ARAS, 2020). 
Em seguida, o presente artigo passará a analisar, dentro dos limites aqui impostos, o sistema processual brasileiro em si, com base nas lições pretéritas de Coutinho, procedendo-se, assim, a uma taxonomia do modelo brasileiro, o qual, como se verá, situa-se, inegavelmente, ainda, como inquisitório.

Por fim, analisa-se o próprio procedimento de arquivamento do inquérito policial: o tradicional, cuja vigência ainda hoje perdura desde 1941, de cariz inquisitório, e o atual, cuja eficácia encontra-se suspensa, de matriz eminentemente acusatória. Ademais, o texto ficará restrito ao arquivamento perante o juízo de primeiro grau de investigações relativas a crimes de ação penal pública $^{5}$.

O objetivo dessa sucessão de ideias, portanto, é demonstrar que o legislador, com a implementação desse novo modelo teórico, passa a introduzir novas características acusatórias no processo penal brasileiro, cuja essência, pelo fato de a gestão da prova ser de natureza triangular, ainda se mantém inquisitória.

\subsection{Metodologia}

A técnica metodológica utilizada é sobretudo a de revisão bibliográfica. Busca-se, com isso, tangenciar as publicações em torno da matéria, fazendo breves incursões, também, no método histórico e dedutivo.

Diante disso, ao método histórico será reservado a expor os argumentos historiológicos, sobretudo nos trechos referentes aos sistemas processuais penais, momento em que serão apresentadas considerações sobre o surgimento desses modelos, com sua respectiva indicação temporal, social e política.

O método dedutivo, por sua vez, é a essência deste artigo. Passa-se a analisar uma legislação nova, cuja vigência sequer foi iniciada. Como bem enunciado por Gimbernart Ordeig, o papel da dogmática penal, dentre muitos, é o de tornar as decisões judiciais previsíveis (1970, p. 170). Previsibilidade, portanto, é o que se busca por meio da técnica dedutiva, destinada a compreender a real dimensão e o verdadeiro suporte de aplicação do objeto analisado.

5 Não será objeto deste artigo, portanto, o arquivamento em face de crimes de ação penal de iniciativa privada ou de competência originária dos tribunais. 


\section{Acusatório vs Inquisitório: uma dicotomia a ser superada? ${ }^{6}$}

“Todos os sistemas processuais são mistos" (COUTINHO, 2009, p. 103). Com essa frase, Jacinto Nelson de Miranda Coutinho inicia um dos mais imprescindíveis artigos de que se tem notícia na história do processo penal brasileiro. Imprescindível porque denuncia um vício interpretativo comum: a de que todos os sistemas sejam mistos porque somam elementos inquisitórios e acusatórios.

Para uma melhor percepção acerca dessa consistência real do conceito de "sistema misto", cumpre, por evidente, fazer um breve transcurso histórico sobre a constituição dos mais afamados sistemas teóricos, a saber, inquisitório e acusatório. Esses dois sistemas processuais, historicamente, atuaram como reflexo da resposta do processo penal diante das exigências do Direito Penal e do Estado de uma determinada época (LOPES JR., 2006, p. 160).

O sistema inquisitório, por primeiro, surge no bojo da Igreja Católica, e tem seu marco histórico em 1215, no IV Concílio de Latrão. A Igreja iniciava as perseguições que um dia tanto repudiou, quando membros seus foram torturados, mortos e perseguidos no início do catolicismo romano.

O réu passa a ser entendido como pecador, detentor de uma verdade a ser extraída (COUTINHO, 2009, p. 105). Daí que a tortura tenha se tornado a tônica da persecução penal, e a confissão a regina probationum. Um modelo, como aponta Coutinho, diabólico, muito embora nascido no seio da Igreja Católica (2009, p. 105).

Nesse processo de base inquisitorial, o endurecimento em face do réu é perceptível por meio de manifestações de utilitarismo judicial, pelo segredo ${ }^{7}$, pelo aumento das penas processuais, pelas absurdas inversões da carga probatória e, sobretudo, pela entrega de mais poderes aos juízes, com a finalidade de que estes pudessem investigar (LOPES JR., 2006, p. 161).

6 Sobre o tema, veja-se o desenvolvimento feito por Alexandre Moraes da Rosa (2015, p. 56-58).

7 Aqui, lembra-se do famoso diálogo no Guia do Mochileiro das Galáxias, entre o Sr. Dent e Arthur, que, com algumas adaptações, ilustra perfeitamente a anedota do segredo em direito penal: - Mas sr. Dent, o projeto estava à sua disposição na Secretaria de Obras há nove meses. - Pois é. Assim que eu soube fui lá me informar, ontem à tarde. Vocês não se esforçaram muito para divulgar o projeto, não é verdade? Quer dizer, não chegaram a comunicar às pessoas nem nada. - Mas o projeto estava em exposição... - Em exposição? Tive que descer ao porão para encontrar o projeto. - É no porão que os projetos ficam em exposição. - Com uma lanterna. - Ah, provavelmente estava faltando luz. - Faltavam escadas, também. - Mas, afinal, o senhor encontrou o projeto, não foi? - Encontrei, sim. Estava em exibição no fundo de um arquivo trancado, jogado num banheiro fora de uso, cuja porta tinha a placa: cuidado com o leopardo. (ADAMS, 2009, p. 21) 
Esse sistema inquisitório de raiz católica nada tem a ver com a inquisitio da República Romana, tida como berço do sistema acusatório (GAVIORNO, 2006, p. 55). Este, por sua vez, desenvolve-se na Inglaterra, a partir de uma ideia de contenção dos Juízos de Deus.

O sistema previa a figura do representante real como um simples garantidor da forma processual, sendo que as partes exerciam, plenamente, o protagonismo do debate. Em outras palavras, " $O$ julgamento se transformava (...) em uma grande disputa entre acusador e acusado, acusação e defesa" (COUTINHO, 2009, p. 107).

Da leitura dos parágrafos acima, talvez já se tenha ideia de algumas características desses sistemas. Um, como se viu, surge para combater o pecador; o outro, para oxigenar o debate entre acusação e réu. Nessa linha, esses sistemas passaram a ser identificados como representantes de certas características específicas.

Quanto ao sistema inquisitório, identificaram-se as seguintes: permanência do julgador; ausência de equilíbrio entre as partes processuais, com evidente protagonismo do juiz; oficialidade da acusação, admitindo que esta seja secreta; formalidade escrita, sigilosidade e não contraditório; tarifação legal da prova; ausência de coisa julgada da sentença; prisão preventiva como regra na persecução (ROSA, 2015, p. 57).

Em relação ao sistema acusatório, por sua vez, constatam-se os seguintes aspectos: o julgador é uma assembleia ou corpo de jurados; as partes são tratadas em pé de igualdade; a ação é popular nos delitos públicos e de iniciativa do ofendido nos privados; o processo é oral, contraditório e público (PRADO, 2005, p. 170); a análise da prova se dá com base na convicção fundamentada do magistrado; a sentença faz coisa julgada; a liberdade do acusado é regra (ROSA, 2015, p. 57$58)$.

\subsection{A gestão da prova como critério diferenciador dos sistemas inquisitórios e acusatórios}

O simples cotejamento entre os dois sistemas puros, a partir das características apontadas acima, revela que ambos, de fato, em absolutamente nada se misturam. A ideia central, porém, e a pedra angular que os tornam essencialmente diferentes, deve girar em torno de se analisar a tomada de postura do magistrado durante a gestão da $\operatorname{prova}^{8}$. É a gestão da prova a mais relevante marca diferencial entre sistema inquisitório e acusatório9.

8 Parte da doutrina vem apontado que o princípio unificante seria a separação inicial das atividades de acusar e julgar. Essa visão parece equivocada. O critério mais seguro é entender que a separação das atividades de acusar 
Por gestão da prova deve-se entender, aqui, a função de fazer aportar provas ao processo. Quando a função de aportá-las for (ou também for) do juiz, o sistema será inquisitório ${ }^{10}$. Se a função for exclusivamente das partes, o sistema será acusatório (COUTINHO, 2009, p. 109).

Diante desse cenário, surgiu o seguinte questionamento: e se, dentro de um mesmo sistema, houver possibilidade de aporte da prova por parte não só do juiz mas também das partes? Em outras palavras, e se, dentro do processo, o juiz, o réu e o acusador puderem, os três, aportarem provas no procedimento penal? Mais: e se suas características se misturarem, ora dando-se ênfase em elementos afeitos ao sistema inquisitório, ora dando-se ênfase em elementos comuns ao acusatório?

Viu-se, na verdade, que o mais comum era justamente essa mescla de caracteres. Os sistemas, em sua totalidade, não mais se revelavam puros, a trazer em si traços exclusivamente acusatórios ou inquisitórios. Passou-se, então, com algum grau de acerto, a dizer que os sistemas processuais todos eram mistos.

O problema é que se essa conclusão, de fato, era verdadeira, sua fundamentação mais ordinária, por outro, era completamente falsa. Isso porque se buscou sustentar que o sistema seria misto já que congregaria elementos do sistema inquisitorial com elementos do sistema acusatório. Buscou-se definir, por assim dizer, que determinado sistema processual seria misto porque na soma de suas características haveriam encontrado elementos inquisitórios e acusatórios. Nada mais falso.

e julgar seja uma característica do sistema, uma dentre tantas, não sendo jamais capaz de servir de princípio informativo do sistema. E isso porque essa separação inicial representa uma falácia, já que é dado ao juiz, ao longo do procedimento, intervir de diversas maneiras, assumindo "um papel ativo na busca da prova ou mesmo na prática de atos tipicamente da parte acusadora” (LOPES JR., 2006, p. 177).

9 Nem todos os autores concordam com essa visão. Em sentido contrário, veja-se (PACELLI; FISCHER, 2017, p. 275): "Registre-se, sobre o tema, a riquíssima pesquisa histórica levada a cabo por Mauro Fonseca de ANDRADE (Sistemas processuais penais e seus princípios retores. Curitiba: Juruá, 2008), (...) O citado autor não compartilha da ideia segundo a qual a definição do modelo processual penal deveria partir da análise da gestão da prova ou de sua responsabilidade. Segundo ele (...) não haveria incompatibilidade alguma entre eventual iniciativa probatória do juiz, em limites legais bem definidos, e um sistema de natureza acusatória." Em Portugal, também em sentido contrário, Teodósio Jacinto aduz que "um dos princípios estruturantes da constituição penal é o princípio acusatório, nos termos do qual só se pode ser julgado por um crime precedendo acusação por parte de um órgão distinto do julgador" (JACINTO, 2009, p. 12).

10 A essa altura já se revela pertinente o seguinte esclarecimento. Prova e processo são expressões utilizadas, nesse contexto, em sentido lato. Como se sabe, processo apenas há a partir do oferecimento da denúncia por parte do órgão acusatório. A partir daí instala-se a chamada persecutio criminis in judicio. Antes disso não há que falar em processo, senão que apenas em fase investigatória. Em regra, os elementos produzidos nessa fase investigatória não são provas, posto que, no mais das vezes, despidas de um elemento central no conceito de prova: a produção em contraditório. 
Em verdade, um sistema processual penal misto não exsurge da somatória dos elementos do dois sistemas puros, a saber, inquisitório e acusatório (COUTINHO, 2009, p. 107). Aduzir dessa maneira seria fomentar uma contradição insuperável, afinal, sistemas, como bem colocado, devem ser entendidos de maneira lógica (SCHÜNEMANN, 1991, p. 31-32). Antilógico, portanto, e muitíssimo contraditório, já que quebra a própria ontologia do que é ser um sistema, dizer que algo é inquisitório e acusatório a um só tempo.

Coutinho, um dos maiores responsáveis pela identificação deste problema no Brasil, passou a demonstrar que, em verdade, o que define a "mesticitude" do sistema não é a congregação dos seus caracteres (COUTINHO, 2009, p. 107).

Os sistemas são mistos porque à sua essência sistêmica (seja ela inquisitória ou acusatória) ligam-se características de outros sistemas teóricos. Não há que se dizer que determinado sistema processual $^{11}$, por exemplo, seja misto, mas que sendo inquisitório, contém momentos acusatórios; ou, sendo acusatório, mergulha em trechos inquisitórios.

Ao esconder-se a real essência do sistema, alcunhando-o misto, perde-se a própria dimensão do debate político. Dizer que determinado sistema é misto é dizer, na prática, que o legislador cedeu às demandas de inquisidores e acusatórios, numa espécie de tentativa de conciliar ambas as partes.

Com isso, atenua-se e põe-se panos frios em violações comezinhas ao direito de defesa, deslocando a carga acusatória das mãos do Ministério Público para as do inquisidor, em flagrante retrocesso à estrutura perseguidora do processo penal surgido a partir do IV Concílio de Latrão.

Com efeito, eventual violação às garantias fundamentais do réu, diz-se, será sanada quando da instrução processual, esta, sim, afirmam, de cunho acusatório. O acusatório posterior passa a exercer uma função de carimbo burocrático dos atos antecessores e violadores de liberdades fundamentais. Como todo carimbo, costuma perder sua força com o tempo, transformando-se em pura e simples retórica canhestra, sedizente (in)capaz de tranquilizar os ânimos dos defensores do princípio dispositivo, que melhor representa os interesses constitucionais acerca do caso penal. Arrematam, afinal: "se lá nos deram inquisitivo (inquérito), aqui lho damos acusatório (processo)"'.

11 Sobre o sistema processual brasileiro, veja-se o tópico seguinte. 
Essa visão bipartite do processo penal não é condizente com o modelo de democracia ancorado na Constituição da República de 1988. Não há mais espaços para, sob a desculpa da fase instrutória ser pseudo-acusatória, sustentar uma fase preliminar inquisitória, em que o juiz pode, ex officio, aportar dados ao procedimento.

Apenas um sistema de base acusatória, ou seja, em que a gestão da prova esteja a cargo da acusação e defesa, faz sobressair os direitos e garantias individuais, proibindo excessos (COUTINHO, 2009, p. 114), em uma estrutura dialética, sem romper com os valores democráticos inspiradores da nossa sociedade (JARDIM, 1983, p. 76).

E aqui, como se verá, a lei 13.964/2019, em que pese não alterar o princípio informador do processo penal, que continua sendo, ainda, inquisitivo, representa um marco avançado ao impedir que o magistrado sirva de filtro diante da promoção de arquivamento do inquérito apresentada pelo Ministério Público. A lei 13.964/2019 exclui, sem rodeios, ao menos neste momento, uma antiga característica inquisitória do sistema processual penal brasileiro.

\subsection{O sistema processual penal brasileiro e o seu núcleo inquisitório}

Tradicionalmente, o sistema processual brasileiro é tido por misto. Argumenta-se, nessa linha, que haveria uma fase inquisitória e uma fase acusatória. Uma espécie de monstro de duas cabeças, ora focado em elementos inquisitórios (inquérito), ora focado em elementos acusatórios (processo) (LOPES JR., 2006, p. 175).

Na lição de Frederico Marques, por sistema processual deve-se entender "a forma, o modelo, o tipo pelo qual o processo, na sua acepção mais ampla, se estrutura, relativamente à relação jurídica que o permeia; ao procedimento que o revela; e à documentação que o registra" (2000, p. 64). É preciso, pois, agregar ao conceito de Marques a noção de que esse sistema deve ser regido por um princípio unificante, dada a necessidade de coesão lógica que fundamenta os sistemas.

Como se viu no tópico 2.1, a qualidade de "misto" tendo por base uma soma de características, sejam elas do inquérito ou do processo, é equivocada. A qualidade do sistema não está na soma de suas características, mas na essência do seu princípio unificante. Mister, por pressuposto, identificar o princípio unificante de cada sistema, para só então etiquetá-lo como inquisitório ou acusatório (LOPES JR., 2006, p. 162), desapegando-se, assim, de um fácil e cômodo rigor aritmético. 
No caso do sistema brasileiro, o princípio unificante é, sem dúvidas, o inquisitório, à guisa das lições já demonstradas por Coutinho, de que a gestão da prova é também atribuição do juiz, pouco importando quantas outras características de cunho acusatório gravitem em torno do sistema. As modificações empreendidas pela lei 13.964/2019 não o tornaram efetivamente acusatório, muito embora tenham trazido diversos elementos afeitos a este sistema, a exemplo da implementação do juiz de garantias (cuja aplicação está suspensa, consoante já dito).

O sistema continua, portanto, inquisitório, e o motivo para tanto é o seguinte: o juiz ainda tem iniciativa probatória. Nesse contexto, o art. $156^{12}$, I e II, do CPP, ainda existente, responsável por atribuir poderes instrutórios ao juiz, externa a adoção do princípio inquisitivo, que funda um sistema inquisitório.

Nas lições de Lopes Jr., esses poderes instrutórios atribuídos ao magistrado "representam uma quebra da igualdade, do contraditório, da própria estrutura dialética do processo" (2006, p. 180). Destrói-se, assim, a mais relevante garantia da jurisdição, que é a imparcialidade do julgador $^{13}$.

É buscando anular um pouco dessa participação super-ativa do magistrado que a lei 13.964/2019 modifica o teor do artigo 28 do CPP, alterando-se a essência daquele procedimento. Com isso, insere-se no próprio sistema inquisitorial mais um trunfo do modelo acusatório, atribuindo-se exclusivamente ao Ministério Público o papel de decidir o destino daquilo a que se lhe destina: o inquérito.

30 antigo e o novo: os modelos de arquivamento do inquérito policial antes e depois da lei $13.964 / 2019$

\subsection{O ainda vigente critério de arquivamento do inquérito policial}

12 Art. 156. A prova da alegação incumbirá a quem a fizer, sendo, porém, facultado ao juiz de ofício: I-ordenar, mesmo antes de iniciada a ação penal, a produção antecipada de provas consideradas urgentes $e$ relevantes, observando a necessidade, adequação e proporcionalidade da medida; II - determinar, no curso da instrução, ou antes de proferir sentença, a realização de diligências para dirimir dúvida sobre ponto relevante.

13 A tomada de postura de juiz é o mais importante aspecto nessa investigação. Se ele passa a poder agir ex officio, determinando a produção de provas, estaremos diante de um sistema regido pelo princípio inquisitivo, já que um sistema essencialmente acusatório não dá ao juiz a capacidade de se fazer investigador. Este sistema espera do juiz um espectador, que avalia objetivamente o fatos a si trazidos, sendo, de acordo com Lopes Jr., mais sábio que experto (2006, p. 180). 
A lei 13.964/2019 alterou sensivelmente a redação referente ao arquivamento do inquérito policial. A partir da novel legislação, muito mais alinhada ao sistema acusatório, não mais é dado ao juiz revisar o pedido de arquivamento sugerido pelo membro do parquet.

A análise das modificações empreendidas pela nova lei pressupõe, antes, a compreensão do antigo modelo de arquivamento do inquérito, regido por elementos escancaradamente inquisitoriais, no qual o juiz poderia discordar da opinião do dominus litis da ação penal.

Saliente-se, no entanto, que o "antigo" modelo de arquivamento é ainda o modelo vigente no ordenamento pátrio, haja vista decisão do Ministro Relator da ADI 6.298 no sentido de suspender a eficácia da lei nova neste ponto específico.

O vigente artigo 28 do Código de Processo Penal enuncia que "se o órgão do Ministério Público, ao invés de apresentar a denúncia, requerer o arquivamento do inquérito policial ou de quaisquer peças de informação, o juiz, no caso de considerar improcedentes as razões invocadas, fará remessa do inquérito ou peças de informação ao procurador-geral, e este oferecerá a denúncia, designará outro órgão do Ministério Público para oferecê-la, ou insistirá no pedido de arquivamento, ao qual só então estará o juiz obrigado a atender."

A legislação em vigência, no ponto, é muito clara: o juiz é a única figura legítima com atribuição para concordar ou discordar do Ministério Público. A concordar, o inquérito será efetivamente arquivado. A discordar, deverá remetê-lo ao Procurador-Geral - ou às Câmaras de Coordenação e Revisão na hipótese de promoção de arquivamento formulada pelo Ministério Público Federal (Lei Complementar 75, de 1993, art. 62, IV) — para que seja tomada qualquer das seguintes providências: ou oferecimento da denúncia, ou designação de outro órgão do Ministério Público para oferecê-la, ou insistência no pedido de arquivamento, ao qual só então estará o juiz obrigado a atender (art. 28 do Código de Processo Penal).

Em tempo, cumpre observar que o arquivamento e o trancamento do inquérito não se confundem. O primeiro caso decorre do encerramento normal das investigações, sem a respectiva propositura da ação penal, seja pelo Ministério público, nos casos de ação penal pública, seja pelo particular, naquelas hipóteses de ação penal privada.

O trancamento, por sua vez, representa o encerramento (ordinariamente) prematuro do inquérito policial. Aqui, a falta de encerramento é a ausência de justa causa para a existência do próprio 
inquérito, não se confundindo com a ausência de justa causa para a ação penal, argumento este afeito ao arquivamento.

No trancamento, o desfecho do inquérito é decretado antes mesmo de eventual elaboração do relatório pelo delegado. Por fim, anote-se que os motivos que ensejam arquivamento e trancamento podem sim ser iguais, a exemplo do dominus litis que entenda que o caso em questão não deve ser processado por atipicidade material dos fatos (BETINI, 2012, p. 44-45).

Se o natural desenrolar do trancamento do inquérito é uma decisão de natureza judicial, a possibilidade de ser dado ao magistrado discordar da promoção de arquivamento do Ministério Público é, sem qualquer dúvida, um resquício inquisitorial que sequer deveria ter sido recepcionado pela Constituição.

Essa possibilidade de o magistrado controlar o arquivamento do inquérito seria uma forma de se proteger o princípio da obrigatoriedade da ação penal, uma indiscutível função anômala, visto que o titular da ação penal é o Ministério Público (art. 129, I, da Constituição Federal).

Não tendo sido, no entanto, declarado não recepcionado, o artigo 28 , na redação anterior à lei 13.964/2019, representa a atual regra do jogo que, mesmo diante de severas críticas, deverá por enquanto ser seguida. A promoção de arquivamento, em outras palavras, será destinada ao juiz.

Essa destinação ao juiz não é exclusividade dos inquéritos cuja competência pertença ao juiz de direito. Também nos casos de inquérito em trâmite perante a Polícia Federal, acompanhado por membro do Ministério Público Federal, deverá eventual promoção de arquivamento ser dirigida ao magistrado.

O ponto diferencial do procedimento dessas duas justiças é que, sendo estadual, o inquérito será encaminhado para o Procurador-Geral de Justiça; sendo a competência da Justiça Federal, o inquérito e sua respectiva promoção de arquivamento serão encaminhados para uma das Câmaras de Coordenação e Revisão do Ministério Público Federal.

Nos dois casos, no entanto, a promoção inicialmente deve ser remetida ao juiz. É o juiz, portanto, quem encaminha para o Procurador-Geral de Justiça ou para a Câmara de Coordenação e Revisão do MPF. Contrario sensu, significa dizer que pelo sistema em vigência, inevitavelmente a ser superado a partir do momento em que as modificações implementadas pela lei 13.964/2019 passarem a viger, não deve o Ministério Público Federal, sob pena de nulidade, remeter a 
promoção de arquivamento diretamente ao órgão de revisão, sem que a promoção antes tenha sido apreciada pelo juiz competente.

\subsection{A nova sistemática de arquivamento do inquérito policial: a efetiva consagração do modelo acusatório}

A lei 13.964/2019 modifica a sistemática inquisitória do arquivamento do inquérito. De acordo com a nova redação do artigo 28 do CPP, “ordenado o arquivamento do inquérito policial ou de quaisquer elementos informativos da mesma natureza, o órgão do Ministério Público comunicará à vítima, ao investigado e à autoridade policial e encaminhará os autos para a instância de revisão ministerial para fins de homologação, na forma da lei”.

O juiz, aqui, deixa de ser responsável por acatar ou não o pedido de arquivamento do Ministério Público. Este, a partir da vigência da lei 13.964/2019, não mais pede ou promove ao juiz, senão que efetivamente determina seu arquivamento, sendo o único competente para tanto, sem qualquer intervenção do Poder Judiciário.

Trata-se de verdadeira decisão de não acusar (BARROS; ARAS, 2020), de postura mais alinhada à constitucional separação de papéis na persecução penal, evitando-se que o magistrado antecipe sua impressão acerca do caráter aparentemente ilícito fato ${ }^{14,15}$.

No mesmo sentido, veja-se o posicionamento de Eugênio Pacelli e Douglas Fischer, já muito antes do início da vigência da nova lei a apontar que não deveria ser da competência do magistrado juízo negativo sobre a propositura da ação penal:

Pensamos que o controle da atuação ministerial, isto é, no sentido de avaliar a correção
do juízo negativo de propositura da ação penal (materializado no pedido de
arquivamento), não deveria ser da competência do juiz, até mesmo de maneira a
preservar, o quanto e ao máximo possível, a imparcialidade do julgador, evitando-se o
seu pronunciamento antecipado sobre o caráter aparentemente ilícito do fato. Talvez,
melhor seria se o citado controle coubesse ao próprio Ministério Público, de ofício, ou
por provocação do ofendido (PACELLI; FISCHER, 2017, p. 71). A relação deixa de ser triangular ${ }^{16}$ (Polícia, Juiz e Ministério Público) e passa a ser apenas entre Polícia e Ministério Público. Se antes o sujeito ativo do arquivamento (o órgão com atribuição

14 Em sentido contrário, confira-se (TORON, 2010, p. 3): "É bem verdade que o Projeto do CPP permitia que o inquérito policial fosse instaurado e depois arquivado pelo próprio representante do MP, sem apreciação do juiz. Diante da inafastabilidade da apreciação pelo Judiciário de qualquer lesão ou ameaça a direito"(CF, art. $\left.5^{\circ}, X X X V\right)$, tal excrescência foi afastada pelo Sen. Renato Casagrande, relator do substitutivo no Senado".

15 Em Portugal, costuma-se chamar essa decisão de não acusar de despacho de abstenção de acusação do Ministério Público (JACINTO, 2009, p. 13). 
para determinar o arquivamento) era o juiz ${ }^{17}$, agora o sujeito ativo do arquivamento passa a ser o Procurador-Geral ou as Câmaras de Revisão.

A decisão a ser tomada, agora, pelas Câmaras de Coordenação e Revisão ou pelo ProcuradorGeral, tem a natureza jurídica de uma decisão material e subjetivamente administrativa, de natureza complexa (JARDIM, 1983, p. 77).

Em partes, antes assim já o era. O juiz que, discordando da promoção inicial de arquivamento, remetia-a ao Procurador-Geral ou às Câmaras, apenas aguardava, na prática, dois resultados: o efetivo oferecimento de denúncia ou uma verdadeira decisão por não acusar (ato jurídico). Nessa última hipótese, o magistrado apenas determinava ao escrivão que arquivasse os autos (mero ato material de colocar alguma coisa guardada em seu lugar próprio: arquivo) (JARDIM, 1983, p. 77).

A fim operacionalizar esse novo regime de aferição da suficiência das razões para arquivar (ARAS, 2020, p. 1), a lei estipula que, ao decidir pelo arquivamento do inquérito, o membro do órgão ministerial deverá dar ciência à vítima (ou a seu representante legal), ao investigado e à autoridade policial $^{18}$.

A partir dessa hipótese, o $\S 1^{\circ}$ do artigo 28, também inserido por ocasião da lei 13.964/2019, passa a prever que "se a vítima, ou seu representante legal, não concordar com o arquivamento do inquérito policial, poderá, no prazo de 30 (trinta) dias do recebimento da comunicação, submeter a matéria à revisão da instância competente do órgão ministerial, conforme dispuser a respectiva lei orgânica".

A nova previsão legal confere ao ofendido a possibilidade de recorrer da decisão de arquivamento emanada do órgão ministerial responsável pelo oferecimento da denúncia. Essa nova tomada de postura por parte do legislador dedica um olhar mais atento ao papel da vítima no processo penal, de comum coadjuvante a (em poucos momentos) protagonista.

16 Uma relação triangular marcada por funções anômalas. De um lado, o delegado de polícia valendo-se, em seu relatório, da Arte Retórica aristotélica, por meio da construção de um discurso persuasivo, desfazendo-se, assim, a expectativa de que produza uma argumentação fundada em raciocínios estritamente demonstrativos (NASCIMENTO, 2015, p. 154-155); do outro, um Ministério Público regido pelo mito da imparcialidade e, por fim, um magistrado dotado de funções inquisitivas.

17 Caricata a expressão utilizada por Aldir Silva, de que o juiz seria uma espécie de intermediário de luxo na tramitação do inquérito policial (SILVA, 2012, p. 18).

18 Como bem observado por Vladimir Aras, "embora a lei não o diga, o Ministério Público também deverá dar ciência ao juiz das garantias, para eventual baixa de distribuição ou de registros e a revogação de medidas cautelares, se for o caso", (ARAS, 2020, p. 1). 
A jurisprudência pacífica, totalmente contrária a essa possibilidade ${ }^{19}$, argumentava, com razão, que inexistiria assistente de acusação na fase do inquérito. De fato, este continua inexistindo, sendo simplesmente possível que a vítima, nos casos em que houver promoção de arquivamento, possa oferecer razão para que assim não se proceda.

Atualmente, a tratativa mais esmiuçada encontra-se na Resolução n. ${ }^{\circ} 181$, de 7 de agosto de 2017, do Conselho Nacional do Ministério Público, que dispõe sobre a instauração e tramitação do procedimento investigatório criminal ${ }^{20}$ a cargo do Ministério Público.

O órgão revisor, à semelhança dos poderes outrora conferidos ao magistrado, poderá manter a decisão de arquivamento ou determinar o prosseguimento das investigações, também podendo já designar outro promotor ou procurador para o oferecimento da denúncia.

Observe-se que mesmo com a adoção de um modelo puramente administrativo de arquivamento, o princípio da obrigatoriedade continua sendo a tônica regente da ação penal. E isso porque embora não mais haja a figura o juiz exercendo a função de controle externo deste princípio, as eventuais decisões de arquivamento precisam estar fundamentas à luz das causas de arquivamento.

É preciso, portanto, que haja motivo para que se arquive ${ }^{21}$. Essa exigência é desdobramento lógico da agora existente possibilidade de a vítima, ou seu representante legal, submeter a matéria à revisão, por meio da apresentação de razões para a apreciação do órgão superior ${ }^{22}$.

Se, por um lado, com a nova redação do art. 28 o legislador libera parte do grande potencial do princípio da oportunidade (ARAS, 2020, p. 3), resta inegável que ainda vige o princípio da

19 [...] 1. Esta Corte Superior firmou o entendimento de que "a vítima de crime de ação penal pública incondicionada não tem direito líquido e certo de impedir o arquivamento do inquérito ou peças de informação" (M S 21.081/DF, Rel. Ministro Raul Araújo, Corte Especial, julgado em 17.6.2015, DJe 4.8.2015).

20 A resolução, sem dúvidas, precisa ser modificada, ampliando seu objeto também para o inquérito policial.

21 Sobre as causas para o arquivamento, $c f$. (JARDIM, 1983, p. 78-80). Para o autor, embora o Código não estabeleça, expressamente, quais seriam as causas de arquivamento, ele prevê os cenários em que o juiz deverá rejeitar a denúncia. Basicamente, eram os pontos elencados no revogado art. 43 do CPP que deveriam nortear a decisão de arquivamento do Ministério Público. Agora, este deverá se orientar de acordo com o art. 395 do CPP e com as possibilidades de absolvição sumária do denunciado. Havendo suporte para uma eventual absolvição sumária em uma eventual ação penal ou também inexistindo justa causa para o exercício da ação penal, deverá o Ministério Público arquivar o inquérito.

22 Esse regramento já era aplicado no âmbito do Ministério Público Federal, naquelas hipóteses em que a abertura do procedimento investigatório criminal se desse por meio de representação. Veja-se o art. $14, \S 1^{\circ}$, da Resolução 77, de 14 de setembro de 2004, do Conselho Superior do Ministério Público Federal. Além do mais, o art. $129, \S 4 .^{\circ}$, da CF, incluído pela Emenda Constitucional n. 45/2004, estabelece que: "aplica-se ao Ministério Público, no que couber, o disposto no art. 93", no qual se incluem a motivação das decisões judiciais e, por conseguinte, a motivação das manifestações do Ministério Público (BADARÓ, 2016, p. 146, nota 57) 
obrigatoriedade, já que o membro do Ministério Público não poderá optar por um arquivamento exclusivamente fundado em argumentos de oportunidade e conveniência. De qualquer maneira, conforme argumenta Vladimir Aras, “com o sistema de revisão interna obrigatória, o espaço de discricionariedade do Ministério Público aumentou. Esta é uma das consequências da entronização do princípio acusatório no artigo $3^{\circ}$ - $A$ do CPP” (ARAS, 2020, p. 3 ).

Com efeito, a busca pela estrutura ideal de processo penal, como bem ilustrado, é um "tema eterno, diante do qual fracassar não seria motivo de vergonha" (SCHÜNEMANN, 2012, p. 632)". O que temos em vista, por enquanto, é que a atual sistemática de arquivamento do inquérito, com a peremptória exclusão do magistrado desse procedimento, representa, sim, uma quadra parcialmente alvissareira em direção ao sistema efetivamente acusatório.

\section{Conclusões}

1. Como se viu, o marco distintivo entre sistema acusatório e inquisitório reside na precisa identificação sobre a tomada de postura dos sujeitos processuais em relação à prova. Quando o juiz passa a ser interessado em sua produção, sendo-lhe possível, ex officio, requerer-lhe, estar-se-á diante de um sistema processual de cunho inquisitório. Quando o juiz não tiver, de qualquer maneira, iniciativa probatória, estar-se-á diante de um sistema essencialmente acusatório.

2. Diante disso, restou claro que o sistema processual brasileiro é, ainda, essencialmente inquisitorial. A previsão geral acerca da gestão da prova, contida no artigo 156, I e II, do CPP, expõe o potencial inquisitivo do magistrado brasileiro, que pode ordenar, mesmo antes de iniciada a ação penal, a produção antecipada de provas.

3. A exclusão do juiz da nova sistemática de arquivamento do inquérito representa, no entanto, a entronização de uma nova característica acusatória no sistema. Esse avanço, por sua vez, está longe de ser suficiente para que etiquetemos o sistema judicial brasileiro como acusatório, já que o núcleo fundante do sistema, com base no estudo sobre a gestão da prova, ainda mostra-se inquisitório, sendo indispensável que se busque modificar, daqui em diante, o art. 156 do Código de Processo Penal, este sim a leitmotiv do sistema inquisitorial brasileiro. 


\section{Referencias}

ADAMS, D. O Guia do Mochileiro das Galáxias. Tradução: Carlos Irineu Da Costa; Tradução: Paulo Fernando Henriques Britto. São Paulo: Arqueiro, 2009.

ARAS, V. O novo modelo de arquivamento de inquéritos e o princípio da oportunidade da ação. Notícias Jurídicas. Disponível em: <https://www.conjur.com.br/2020-jan-12/vladimir-arasmodelo-arquivamento-inqueritos>. Acesso em: 1 jan. 2020.

BADARÓ, G. H. R. I. Processo penal. 4.a edição revista, atualizada e ampliada ed. São Paulo, SP, Barsil: Revista dos Tribunais, 2016.

BARROS, F. D.; ARAS, V. O arquivamento do inquérito policial pelo ministério público após a Lei Anticrime. Notícias Jurídicas. Disponível em: <http://genjuridico.com.br/2020/01/09/inquerito-policial-lei-anticrime/>. Acesso em: 25 mar. 2020.

BETINI, A. O trancamento do inquérito policial. Dissertação (Mestrado)—São Paulo: Universidade de São Paulo, 2012.

COUTINHO, J. N. DE M. Sistema acusatório. Cada parte no lugar constitucionalmente demarcado. Revista de Informação Legislativa, 46. n. 183, set. 2009.

GAVIORNO, G. Garantias constitucionais do indiciado no inquérito policial. Dissertação (Mestrado)_-Vitória: Faculdades Integradas de Vitória, 2006.

JACINTO, F. T. O modelo de processo penal entre o inquisitório e o acusatório: repensar a intervenção judicial na comprovação da decisão de arquivamento do inquérito. Revista do Ministério Público, v. 30, n. 118, p. 5-44, jul. 2009.

JARDIM, A. S. Arquivamento e desarquivamento do inquérito policial. Revista de Direito Penal, n. 35, p. 76-89, 1983.

JARDIM, A. S. Primeiras impressões sobre a lei $\mathbf{1 3 . 9 6 4 / 1 9}$, aspectos processuais. Notícias Jurídicas. Disponível em: <https://www.migalhas.com.br/depeso/318477/primeiras-impressoessobre-a-lei-13964-19-aspectos-processuais>. Acesso em: 25 mar. 2020.

LOPES JR., A. Introdução Crítica ao Processo Penal. Fundamentos da Instrumentalidade Constitucional. 4. ed. Rio de Janeiro: Lumen Juris, 2006.

MARQUES, F. Elementos de direito processual penal. 2. ed. Campinas: Millenniium, 2000. v. 1

NASCIMENTO, Á. B. O poder no discurso do delegado de polícia. Análise de argumentos retóricos construídos em Relatórios Finais de Inquéritos Policiais. Tese de DoutoradoMinas Gerais: Universidade Federal de Minas Gerais, 2015. 
ORDEIG, G. ¿Tiene un futuro la dogmática jurídico pena? In: Estudios de Derecho Penal. 3. ed. Madrid: Civitas, 1970.

PACELli, E.; FISCHER, D. Comentários ao Código de Processo Penal e sua Jurisprudência. 9. ed. São Paulo: Atlas, 2017.

PRADO, G. Sistema acusatório: a conformidade constitucional das leis processuais penais. 3. ed. Rio de Janeiro: Editora Lumen Juris, 2005.

ROSA, A. M. DA. A teoria dos jogos aplicada ao processo penal. 2. ed. Santa Catarina: Empório do Direito, 2015.

SCHÜNEMANN, B. Intruducción al razionamento sistemático en Derecho Penal. El sistema moderno del derecho penal. Cuestiones fundamentales. Estudios en honor de Claus Roxin en $\mathbf{5 0}^{\mathbf{0}}$ aniversario, n. 1, p. 31-80, 1991.

SCHÜNEMANN, B. Audiência de instrução e julgamento: modelo inquisitorial ou adversarial? Sobre a estrutura fundamental do processo penal no $3 .^{\circ}$ milênio. In: GRECO, R.; MARTINS, A. C. (Eds.). . Direito Penal como Crítica da Pena: estudos em homenagem a Juarez Tavares por seu $7^{\circ}$ aniversário em 2 de setembro de 2012. Madrid: Marcial Pons, 2012.

SILVA, A. J. V. DA. Ministério público, polícia e o destino dos inquéritos. Revista do Ministério Público do Estado do Pará, v. 7, n. 7, p. 17-24, 2012.

TORON, A. Z. Inquérito só no MP e bye, bye Ação Penal Privada. Boletim IBCCRIM, v. 18, n. 213, p. 3-5, 2010. 